\title{
$\mathrm{HFC}$ 망에서 대용량 방송서비스를 위한 채널 결합 기반 전송 방식 및 시뮬레이터 개발
}

\author{
신 현 철a), 이 동 열a), 유 웅 식), 최 동 준 ${ }^{\mathrm{b})}$, 이 채 우 ${ }^{\text {a }}$
}

\section{Transmission Method and Simulator Development with Channel bonding for a Mass Broadcasting Service in HFC Networks}

\author{
Hyunchul Shin ${ }^{\text {a) }}$, Dongyul Lee ${ }^{\text {a) }}$, Woongshik You ${ }^{\text {b) }}$, Dongjoon Choi ${ }^{\text {b) }}$, and Chaewoo Lee ${ }^{\text {a) }}$ \\ 요 약
}

최근에는 UHD(Ultra High Definition) 방송과 같은 단일 채널 전송용량을 초과하는 새로운 대용량 방송 서비스들이 소개되고 있다. 이러 한 대용량 방송 콘텐츠를 전송하기 위해 주로 통신 채널을 통한 데이터 전송에 사용되던 채널 결합 기술들을 적용한 솔루션들이 검토되고 있 다. HFC(Hybrid Fiber Coaxial) 망에서는 양방향 데이터 전송서비스를 제공하기 위해서 적용하고 있는 DOCSIS 3.0(Data Over Cable Service Interface Specification 3.0) 규격이 상/하향 채널 결합 기술을 지원하고 있다. 주로 하향 채널을 이용한 단방향 전송 특성을 갖는 방 송서비스에 이러한 채널 결합 기술을 적용하기 위해서는 DOCSIS 3.0 규격과는 다른 전송 방식에 관한 연구가 필요하다. 또한, 방송을 위해 다수의 전송 채널을 점유하는 대용량 방송 콘텐츠의 특성 상 기존과 같은 $\mathrm{CBR}$ (Constant Bit Rate) 전송보다는 전송 대역 효율 측면에서 유 리한 VBR(Variable Bit Rate) 전송에 관한 연구필요성도 제기되고 있다. 이와 더불어 전송 지연 및 지터에 민감한 방송서비스의 특성 상 채 널 결합을 위한 채널 할당 및 전송 스케줄링에 관한 연구도 필요하다. 본 논문에서는 HFC 망에서 UHD(Ultra High Definition) 방송콘텐츠 와 같은 대용량 방송콘텐츠를 전송하기 위해서 채널 결합 기반의 VBR 방송콘텐츠 전송 방식을 제안하고, OPNET 기반의 전송 시뮬레이터 를 개발하여 제안한 전송 방식의 성능을 평가한다. 이를 위해, HFC 망에서 대용량 방송콘텐츠를 전송하기 위한 다양한 시나리오를 정의하고, 전송 시뮬레이터를 이용하여 각 시나리오별 전송 성능을 평가한다. 개발된 시뮬레이터를 통해서 HFC 망에서 효율적으로 대용량 방송서비스 를 제공하기 위해 VBR 콘텐츠 전송 및 채널 결합 기술의 필요성을 검토하고 전송 시나리오 별 전송 성능을 평가한다. 이를 통해 개발된 시 뮬레이터는 향후 효율적인 대용량 방송콘텐츠 전송 기술 및 시스템 개발에 활용될 수 있을 것으로 기대된다.

\begin{abstract}
Massive broadcasting contents such as UHD(Ultra High Definition) TV which requires multi-channel capacity for transmission has been introduced in recent years. A transmission scheme with channel bonding has been considered for transmission of massive broadcasting contents. In HFC(Hybrid Fiber Coaxial) networks, DOCSIS 3.0(Data Over Cable Service Interface Specification 3.0) has already applied channel bonding schemes for up/downstream of data service. A method unlike DOCSIS 3.0 is required to introduce a channel bonding scheme in the broadcasting service having unidirectional transmission with a downstream. Since a massive broadcasting content requires several channels for transmission, VBR(Variable Bit Rate) transmission has been emerging for the bandwidth efficiency. In addition, research on channel allocation and resource scheduling is required to guarantee QoS(Quality of Service) for the broadcasting service based on VBR. In this paper, we propose a transmission method for mass broadcasting service in HFC network and show the UHD transmission simulator developed to evaluate the performance. In order to evaluate the performance, we define various scenarios. Using the simulator, we assess the possibility of channel bonding and VBR transmission for UHD broadcasting system to provide mass broadcasting service efficiently. The developed simulator is expected to contribute to the efficient transmission system development of mass broadcasting service.
\end{abstract}

Keyword : UHDTV, Channel Bonding, HFC, CATV, Broadcasting 


\section{I. 서 론}

세계 주요 국가에서는 $\mathrm{HD}$ (High Definition) 방송이 보편 화되었다. $\mathrm{HD}$ 방송은 $1024 \times 720,1280 \times 720$ 등의 화면 해상 도를 갖는 $\mathrm{HD}$ 방송콘텐츠를 사용하고 있으며, 최대 1980x1020의 화면 해상도 한계를 가지고 있어 60 인치 이 상의 대형 디스플레이 장치에서는 화질 열화가 발생된다 ${ }^{[1]}$. 이와 같은 화질 열화 문제를 해결하기 위해, 대형 디스플레 이 장치에서의 방송을 위한 차세대 방송콘텐츠로서 UHD(Ultra High Definition) 방송과 같은 대용량 방송서비 스 기술 개발이 활발히 진행 되고 있다 ${ }^{[1]}$. 대용량 방송서비 스는 기존의 $\mathrm{HD}$ 화질(1280x720픽셀) 대비 4 배(4K $\mathrm{UHD}: 3840 \times 2160$ 픽셀)에서 16 배(8K UHD:7680x4320픽 셀)이상의 높은 해상도 방송콘텐츠 전송을 목적으로 하며, 대용량 방송서비스를 위한 방송 기술은 콘텐츠 획득 기술, 부호화 기술, 전송 기술, 디스플레이 및 STB(Set-Top Box) 기술 분야로 분류 된다 ${ }^{[2]}$.

현재의 국내 방송시스템에서 전체 가구 수의 약 $80 \%$ 를 점유하는 케이블 TV 방송에서HFC(Hybrid Fiber Coaxial) 망에서의 전송 방식은 $6 \mathrm{MHz}$ 단위의 물리계층을 한 채널로 하며, 각 채널에서는 256QAM(Quadrature Amplitude Modulation) 변조방식으로 최대 $38.8 \mathrm{Mbps}$ 의 전송속도로 $\mathrm{MPEG}-$ $2 \mathrm{TS}$ (Transport Stream)를 전송한다 ${ }^{[3]}$. 하지만, 대용량 방송 서비스를 위해서는 기존의 케이블 TV 방송의 압축 방식인 MPEG-2 사용 시 기존 $\mathrm{HD}$ 방송콘텐츠 전송속도(19.4 $\mathrm{Mbps}$ ) 대비 약 16 배의 전송속도인 $310 \mathrm{Mbps}$ 이상의 전송속 도가 요구된다. 향후 H.264 압축 방식을 사용 시에도 약 $160 \mathrm{Mbps}$ 이상의 전송속도가 예상되므로 단일 채널을 통해 방송콘텐츠를 전송하는 기존의 방식은 대용량 방송콘텐츠 를 전송하는데 부적합하다 ${ }^{[4]}$. 이에 HFC 망에서 대용량 방 송콘텐츠 전송을 위한 새로운 전송 기술이 요구된다.

$\mathrm{HFC}$ 망에서 대용량 방송콘텐츠에 대한 전송 기술은 크

\footnotetext{
a) 아주대학교 전자공학과

Division of Electrical and Computer Engineering, Ajou University

b) 한국전자통신연구원 방송통신융합연구부문 디지털CATV시스템연구팀

Digital CATV System Research Team, ETRI

‡ 교신저자 : 이채우(cwlee@ajou.ac.kr)

· 접수일(2011년5월17일),수정일(2011년8월9일), 게재확정일(2011년8월16일)
}

게 두 가지 방식으로 구분될 수 있다. 첫째는 물리 계층의 단일 채널 대역을 확장하여 새로운 채널을 구성하는 방식 이다. 이 방식은 기존의 단일 채널 대역만을 확장하여 기존 전송 방식으로 대용량 방송콘텐츠 전송이 가능한 반면에, 물리 계층의 채널을 새로 구성하기 때문에 표준 제정 및 법제 정비 등 상당한 시간이 소요되는 문제를 갖는다. 둘째 는 기존의 채널대역을 유지하면서 다수개의 채널을 단일의 논리적인 채널로 만드는 채널 결합(channel bonding)기법 을 통한 기술 개발이다. 이 방식은 기존 정책 및 표준을 사 용하기 때문에, 단일 채널 대역을 확장하는 방식보다 빠른 기술 개발이 이루어질 수 있다. 또한, $\mathrm{HFC}$ 망에서는 고속 의 데이터 전송을 위해서 채널 결합 기법을 도입한 DOCSIS 3.0(Data Over Cable Service Interface Specification 3.0) 표준 ${ }^{[5]}$ 규격이 사용되고 있기 때문에, HFC 망에 서의 채널 결합 기법은 방송서비스를 위한 보완을 통한 적 용이 용이할 수 있다. 따라서 본 논문에서는 채널 결합 기반 의 전송 기술에 대하여 연구한다.

현재, HFC 망에서는 데이터 전송을 위해서 DOCSIS 3.0 규격을 사용한다. 그러나, $\mathrm{HFC}$ 망에서 방송서비스와 데이 터 전송서비스는 서로 호환되지 않기 때문에 DOCSIS 3.0 규격을 방송서비스에 그대로 적용할 수 없다. 대표적으로, 데이터 전송에서는 처리율(throughput)이 중요한 성능평가 기준인 반면, 서비스 품질 보장 $(\mathrm{QoS})$ 이 중요한 방송서비스 의 경우 지연, 지터, 패킷 손실률이 중요한 성능평가 기준이 된다. 따라서 방송서비스 전송에서는 데이터 처리율을 높 이기 위한 전송 기술인 DOCSIS 3.0 규격과는 다른 전송 기술이 필요하다. 또한 효율적인 전송대역 사용을 위해 향 후 대용량 방송서비스에서의 VBR(Variable Bit Rate) 콘텐 츠 전송이 예상된다. $\mathrm{VBR}$ 콘텐츠 전송은 일정한 전송 속도 로 전송되는 $\mathrm{CBR}$ (Constant Bit Rate) 콘텐츠 전송과 달리 콘텐츠에 따라 전송 속도의 변화가 심하다. 따라서 VBR 콘텐츠 전송을 위해서 방송콘텐츠의 트래픽 특성에 대한 분석이 필요하다.

본 논문에서는 $\mathrm{HFC}$ 망에서 UHD(Ultra High Definition) 방송콘텐츠와 같은 대용량 방송콘텐츠를 전송하기 위해서 채널 결합 기반의 전송 방식을 제안하고, OPNET 기반의 전송 시뮬레이터를 개발하여 제안한 전송 방식의 성능을 
평가한다. 시뮬레이터는 $\mathrm{HFC}$ 망에서 $\mathrm{VBR}$ 콘텐츠 전송과 채널 결합 기술의 필요성을 보이는 것을 목표로 제작되었 으며, 이를 통해 대용량 방송콘텐츠 전송 기술의 방향을 제 시하고자한다.

본 논문의 구성은 다음과 같다. 2장에서는 먼저 $\mathrm{HFC}$ 망 에서 방송콘텐츠 전송 및 채널 결합 기술에 대해서 설명한 다. 3장에서는 $\mathrm{HFC}$ 망에서 대용량 방송서비스를 위한 채널 결합 기반의 VBR 콘텐츠 전송 방식을 제안하고, 대용량 방송콘텐츠 전송 시뮬레이터의 설계 구성 및 구조를 설명 한다. 4장에서는 대용량 방송콘텐츠 전송 시뮬레이터로부 터 제안한 전송 방식의 성능 평가 및 구현된 결과를 소개한 다. 마지막으로 논문의 내용을 정리한다.

\section{II. 관련 연구}

본 장에서는 대용량 방송서비스 전송 시스템 개발을 위 해 필요한 기술들에 대해서 설명한다. 먼저 현재 사용되고 있는 $\mathrm{HFC}$ 망에서의 방송콘텐츠 전송 방식에 대해서 설명 한다. 또한 $\mathrm{HFC}$ 망에서 데이터 전송을 위해서 채널 결합을 사용하는 DOCSIS 3.0에 대해서 설명한다. DOCSIS 3.0을 통해 $\mathrm{HFC}$ 망에서 채널 결합 기술 도입의 필요성을 제시하 고자 하였으며, 마지막으로 고효율 전송을 위해 필요한 $\mathrm{VBR}$ 콘텐츠 전송 기술에 대해서 설명하였다.

\section{HFC 망에서의 방송콘텐츠 전송 방식}

그림 1 은 $\mathrm{HFC}$ 망에서 방송과 데이터망의 전송 시스템 구조를 보여준다. 방송과 데이터 망은 기본적으로 물리적 으로 동일한 전송망을 사용하여 구성된다. 그림 1 과 같이 데이터 망은 CMTS(Cable Modem Termination System)를 통해서 광단국(ONU;Optical Network Unit)까지는 성형 구 조로 광케이블을 이용하여 이뤄지고 광단국으로부터 개별 가구까지는 수지형 구조로 동축케이블을 이용하여 전송된 다. 반면 방송망의 경우 전송 매체는 헤드엔드로부터 광단 국까지는 성형 구조로 광케이블을 이용하여 전송하고 광단 국으로부터 개별가구까지는 데이터 전송과 동일한 수지형
구조로 동축케이블로 전송된다마.

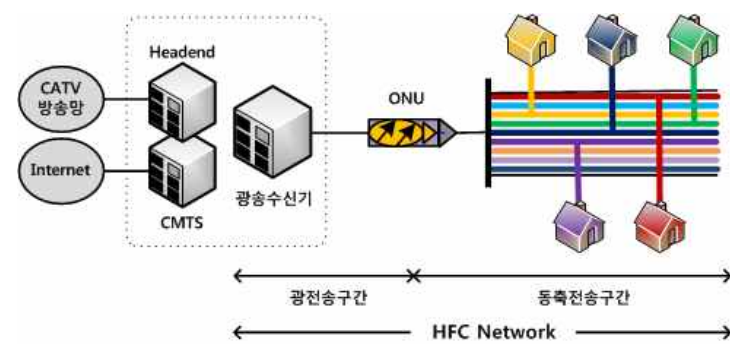

그림 1. 케이블 망 구조

Fig. 1. Structure of cable network

$\mathrm{HFC}$ 망에서 방송을 위한 국내표준으로는 케이블랩스 (CableLabs)에서 제정한 오픈케이블(OpenCable) 방식이 사용되고 있다. 오픈케이블 규격은 디지털 방송을 위한 표 준 규격으로 헤드엔드 시스템 정합, 케이블 네트워크 정합 등 방송을 위한 전반적인 사항에 대한 표준을 정의하고 있 다 ${ }^{[6]}$. 그림 2는 케이블랩스에서 제정한 방송과 데이터 전송 프로토콜 구조를 보여준다.

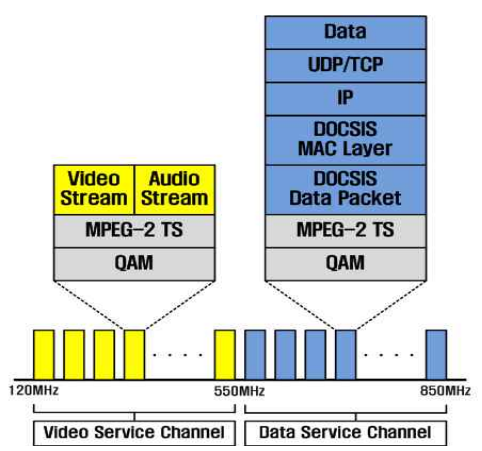

그림 2. $\mathrm{HFC}$ 망에서의 디지털 방송과 데이터 전송 구조

Fig. 2. Transmission stack of digital broadcasting and data in HFC network

오픈 케이블 방식은 비디오 및 오디오 스트림 전송을 위 해 $6 \mathrm{MHz}$ 단위의 물리계층을 한 채널로 하며, 각 채널은 MPEG-2 TS를 256QAM 변조하여 최대 $38.8 \mathrm{Mbps}$ 의 전송 속도를 제공한다 ${ }^{[3]}$. 현재 $\mathrm{HFC}$ 망에서는 하나의 $\mathrm{HD}$ 콘텐츠 를 서비스하기 위해서 $\mathrm{CBR}$ 콘텐츠 전송 방식으로 약 $19.4 \mathrm{Mbps}$ 의 대역폭을 사용하여 단일 채널로 전송하고 있 
다. 기존 방송콘텐츠와는 달리 대용량의 방송콘텐츠를 갖 는 대용량 방송서비스는 전송을 위해 기존 $\mathrm{HD}$ 방송콘텐츠 전송률 대비 약 16 배 이상의 전송률이 요구된다. 즉, 기존의 $\mathrm{HFC}$ 망에서의 전송 방식으로는 단일 채널로 약 $310 \mathrm{Mbps}$ 이상의 전송속도가 요구되는 대용량 방송콘텐츠를 전송하 는 것이 불가능하다. 또한 각각의 방송마다 대용량 콘텐츠 가 전송되기 때문에 전체 주파수 자원이 부족하게 되는 문 제가 존재하게 된다. 이로 인해 고효율 전송 방식이 필요하 여 향후 대용량 방송서비스를 위한 기술로 채널 결합 및 $\mathrm{VBR}$ 콘텐츠 전송 기술 도입이 필요하다 ${ }^{[7]}$.

\section{DOCSIS 3.0 채널 결합 기법}

채널 결합 기법은 다수개의 독립된 물리 계층을 $\mathrm{MAC}$ 계 층에서 결합하여 상/하향 최대 전송 속도를 증가시키는 기 술을 말한다. $\mathrm{HFC}$ 망에서의 데이터 전송 프로토콜인 DOCSIS 3.0에서는 CMTS와 케이블 모뎀(Cable Modem) 간에 데이터 전송 속도를 증가시키기 위해 채널 결합 기법 이 사용된다 ${ }^{[5]}$.

DOCSIS 3.0 표준에서는 4 개의 $6 \mathrm{MHz}$ 채널을 결합하여 상/하향 대역폭을 각각 $120 \mathrm{Mbps}, 160 \mathrm{Mbps}$ 으로 확대한다. 상/하향 스트림을 동시에 사용이 가능하며, 상/하향 채널에 대한 제어는 독립적으로 이루어진다. DOCSIS 3.0 이전의 프로토콜은 단일 채널을 통해 데이터를 전송하였지만 DOCSIS 3.0에서는 채널 결합을 통해 데이터를 전송하기 때문에 기존의 데이터 전송 방식과 다른 전송 방식이 요구 된다. 처리율이 중요한 성능 요소인 데이터 통신의 특성상 DOCSIS 3.0에서 하향 전송 연구는 상대적으로 단순한 반 면 다수의 서비스 요청자가 존재하여 이들 간의 충돌 문제 가 존재하는 상향은 채널 결합 방식, 채널 별 대역할당 방 법, 스케줄링 방법 등 다양한 연구가 진행되고 있다 ${ }^{[8-10]}$.

이러한 DOCSIS 3.0 표준은 인터넷 트래픽과 같은 데이 터 통신을 위한 병렬전송 방식이기 때문에 처리율이 중요 한 요소가 된다. 반면, 실시간 방송서비스에서는 지연과 지 터같은 $\mathrm{QoS}$ 파라미터가 중요한 요소이기 때문에 DOCSIS 3.0 표준의 수정이 요구된다. 또한 $\mathrm{HFC}$ 망에서의 데이터 통신은 IP와 DOCSIS 3.0 MAC을 사용하여 MPEG-2 TS로

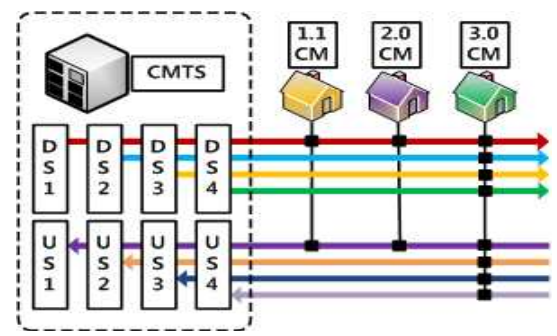

그림 3. DOCSIS 3.0 채널 결합 개념도

Fig. 3. Channel bonding concept of DOCSIS 3.0

전송되지만, 방송서비스는 그림 2와 같이 IP와 DOCSIS $\mathrm{MAC}$ 를 사용하지 않고 MPEG-2 TS로 전송한다. 이러한 전 송 방식의 차이 때문에, 기존의 DOCSIS 3.0 표준 적용이 불가능하다. 따라서 이러한 문제들이 존재하기 때문에, 대 용량 방송서비스를 위한 새로운 전송 방식이 필요하다. 본 논문에서는 대용량 방송서비스의 전송 문제를 해결하기 위 하여 채널 결합 기술을 이용한 다중 채널 결합 기반 대용량 방송콘텐츠 전송 방식을 제안한다.

\section{VBR 전송 기술}

$\mathrm{SD}$ (Standard Definition)TV와 HDTV의 경우 적은 전송 용량으로 인해 안정성을 위해서 $\mathrm{CBR}$ 형태로 방송을 전송 하였지만 대용량 방송콘텐츠의 경우 단일 채널 용량이상의 큰 전송용량으로 인해 고효율 전송 방식이 요구된다. 이로 인해 채널 결합 기술뿐만이 아니라 통계적 다중화 이득을 얻기 위하여 $\mathrm{CBR}$ 형태가 아닌 $\mathrm{VBR}$ 형태의 전송 방식이 요구된다. 그러나 VBR 콘텐츠 전송의 경우 $\mathrm{CBR}$ 콘텐츠 전송에 비해 전송 시스템의 안전성이 상대적으로 낮아 안 전성 분석이 필요하다. 또한 VBR 콘텐츠 기반 대용량 방송 서비스를 위한 시그널링 기법 및 다양한 스케줄링 기술 개 발이 필요하다.

\section{III. 채널 결합 기반의 전송 방식 제안 및 시뮬레이터 개발}

본 장에서는 $\mathrm{HFC}$ 망에서 대용량 방송서비스를 위한 채 
널 결합 기반의 VBR 콘텐츠 전송 방식을 제안한다. 또한 제안된 전송 방식으로 설계된 시뮬레이터의 구성 및 구조 를 설명한다.

\section{1. 대용량 방송서비스를 위한 채널 결합 기반 전송 방식 제안}

본 장에서는 $\mathrm{HFC}$ 망에서 채널 결합 기반 대용량 VBR 방송콘텐츠 전송 방식을 제안한다. 기본적으로 다채널 결 합 지원을 위한 전송 시스템의 구조는 그림 4 와 같이 간략 화 할 수 있다. 그림 4에서 스트림 스플리터(Stream Splitt$\mathrm{er}$ )는 헤드엔드 내에서 각 채널로 패킷이 분배되는 것을 간 략화한 부분이다. 다수의 방송콘텐츠들은 하나의 스트림형 태로 다중화 되어서 스트림 스플리터에 들어오며, 스트림 스플리터는 $\mathrm{QoS}$ 요구사항을 만족하도록 각 프로그램마다 채널을 할당하고, 한 채널에 대하여 프로그램간의 패킷 스 케줄링을 결정하고 매체제어를 수행하여 각 채널에 전달된 다. 그림 4에서 $\mathrm{HFC}$ 망은 헤드엔드에서 나온 스트림이 $\mathrm{HFC}$ 망을 통하여 전송되는 과정을 나타낸다. 그림 4에서의 스트림 디코더(Stream Decoder)는 셋탑 박스의 스트림 디 코더 역할을 간략화한 부분으로 채널 결합을 통해서 전송 된 패킷들의 재정렬 및 재조합 후 콘텐츠별 $\mathrm{TS}$ 로 출력하는 역할을 담당한다.

본 연구에서는 대용량 방송서비스를 위한 채널 결합 기 술과 VBR 전송의 가능성을 검토하는 것이 목적이기 때문 에 모든 채널을 결합하여 모든 프로그램이 할당되는 방식
을 사용하였으며, TS 패킷의 스케줄링 방식으로 $\mathrm{FCFS}$ (First-Come First-Served) 방식이 사용되었다. 또한 DOCSIS 3.0 MAC에서는 채널 결합을 위한 헤더를 두어 각 패킷에 시퀀스 넘버를 붙여 패킷 순서를 파악했지만, 본 연구에서는 채널 결합을 위한 추가적인 헤더를 사용하지 않고 MEPG-2 TS 패킷 헤더의 continuity counter를 활용하 여 다중 채널로부터 패킷을 순서대로 재결합 할 수 있도록 하였다.

\section{2. 전송 시뮬레이터 개발}

대용량 방송서비스의 전송 시뮬레이터는 그림 5 와 같이 크게 입력부, 시뮬레이션부, 출력부로 구성되며 GUI를 통 해서 제어 된다. 입력부는 사용자로부터 다양한 시뮬레이 션을 선택할 수 있는 기능을 갖는다. 시뮬레이션부는 그림 5 와 같이 크게 4 가지의 시뮬레이션 파트로 구성되고 각 파 트는 세부 시나리오를 갖는다. 시뮬레이션 파트 I의 목적은 $\mathrm{QoS}$ 성능 파라미터에 따른 방송콘텐츠 화질 열화 성능 평 가에 있으며, 시뮬레이션 파트 ㅍ는 방송콘텐츠 및 영상 압 축방식에 따른 전송 시뮬레이션을 제공하고, 시뮬레이션 파트 III는 $\mathrm{CBR}$ 과 $\mathrm{VBR}$ 콘텐츠 전송에 따른 통계적 다중화 이득을 성능 분석한다. 마지막으로 시뮬레이션 파트 $\mathrm{IV}$ 는 제안된 전송 시나리오에서 $\mathrm{TS}$ 패킷의 매체접속 과정을 OPNET 시뮬레이터에 의해 만들어진 추적 파일을 사용하 여 애니메이션으로 보여준다. 정해진 시나리오는 OPNET 시뮬레이터에 의해서 결과가 추적 파일로 만들어져 데이터

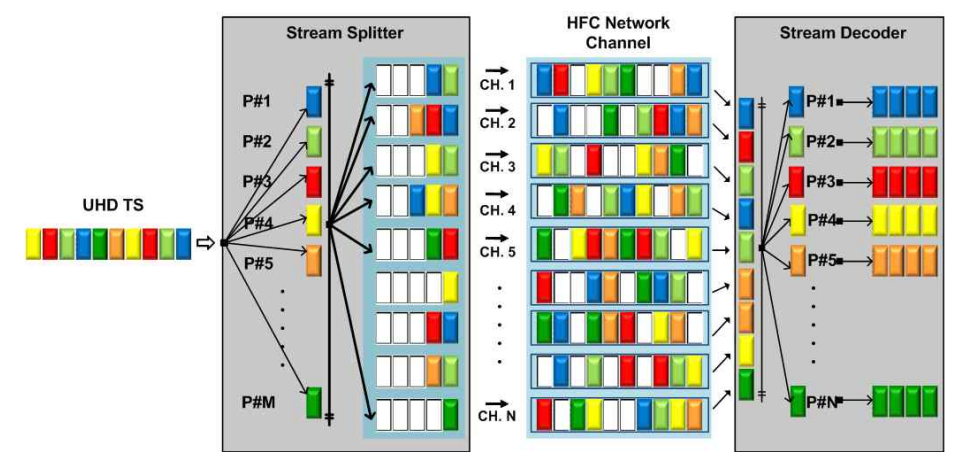

그림 4. 대용량 방송콘텐츠 전송 구조

Fig. 4. Transmission structure of massive broadcasting contents 
베이스에 저장된다. 출력부는 시뮬레이션 결과로부터 받은 데이터 기반으로 하여 그래프, 영상 또는 애니메이션으로 나타내는 역할을 한다. 그림 6은 실제 구현된 시뮬레이터를 보여준다.

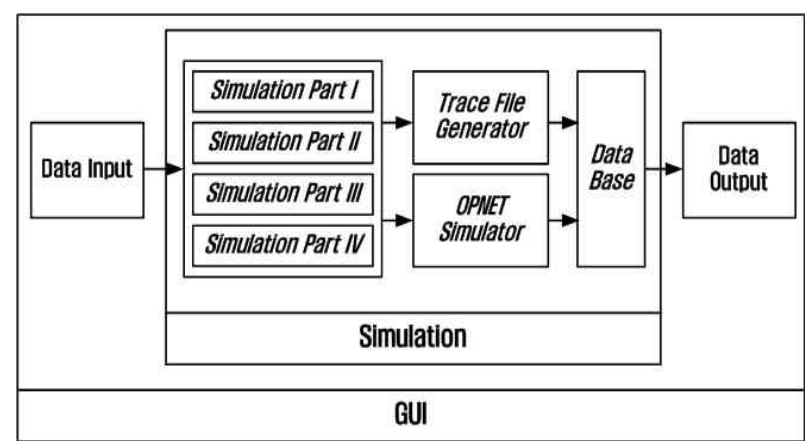

그림 5. 대용량 방송콘텐츠 전송 시뮬레이터의 구성도

Fig. 5. The composition of the massive broadcasting contents transmission simulator

\section{IV. 성능 평가}

본 장에서는 제작한 시뮬레이터를 이용하여 제안한 전송
방식을 평가한다. 또한, 시뮬레이션을 통해 전송 기술의 필 요성을 제시하고, 대용량 방송서비스의 전송 애니메이션을 수행하여 대용량 방송서비스의 전송 방식에 대한 이해를 돕는다.

대용량 방송콘텐츠 전송 시뮬레이터의 파트 I의 목적은 $\mathrm{QoS}$ 성능 파라미터에 따른 손실률과 그 때의 방송콘텐츠 화질 열화를 비교 분석하는 것이다. 방송콘텐츠 전송 중에 발생하는 지연, 지터 등의 $\mathrm{QoS}$ 파라미터 변화에 따라서 패 킷 손실률을 제시하며, 방송콘텐츠의 화질 열화 정도를 방 송콘텐츠의 재생을 통하여 시각적으로 확인한다. 시뮬레이 션의 결과로부터 대용량 방송콘텐츠 전송 과정 중에 발생 하는 지연과 지터에 따라서 실제 콘텐츠의 화질 열화 정도 를 파악할 수 있다.

시뮬레이션의 소스는 Full HD인 Sista의 Push Push 콘텐 츠로 사용하며, 이 콘텐츠의 최대 전송속도는 $20.21 \mathrm{Mbps}$, 평균 전송속도는 $17.29 \mathrm{Mbps}$ 이다. 채널 용량은 $38.8 \mathrm{Mbps}$ 이 고, 지연 한계와 지터 한계는 ITU-T Y.1541 표준을 따라 방송을 위한 네트워크 $\mathrm{QoS}$ 요구사항인 $100 \mathrm{~ms}, 50 \mathrm{~ms}$ 를 각 각 사용한다 ${ }^{[11]}$. 본 시뮬레이션에서는 각각의 한계를 넘는 경우 패킷 손실로 처리한다. 표 1은 사용된 Sista의 Push

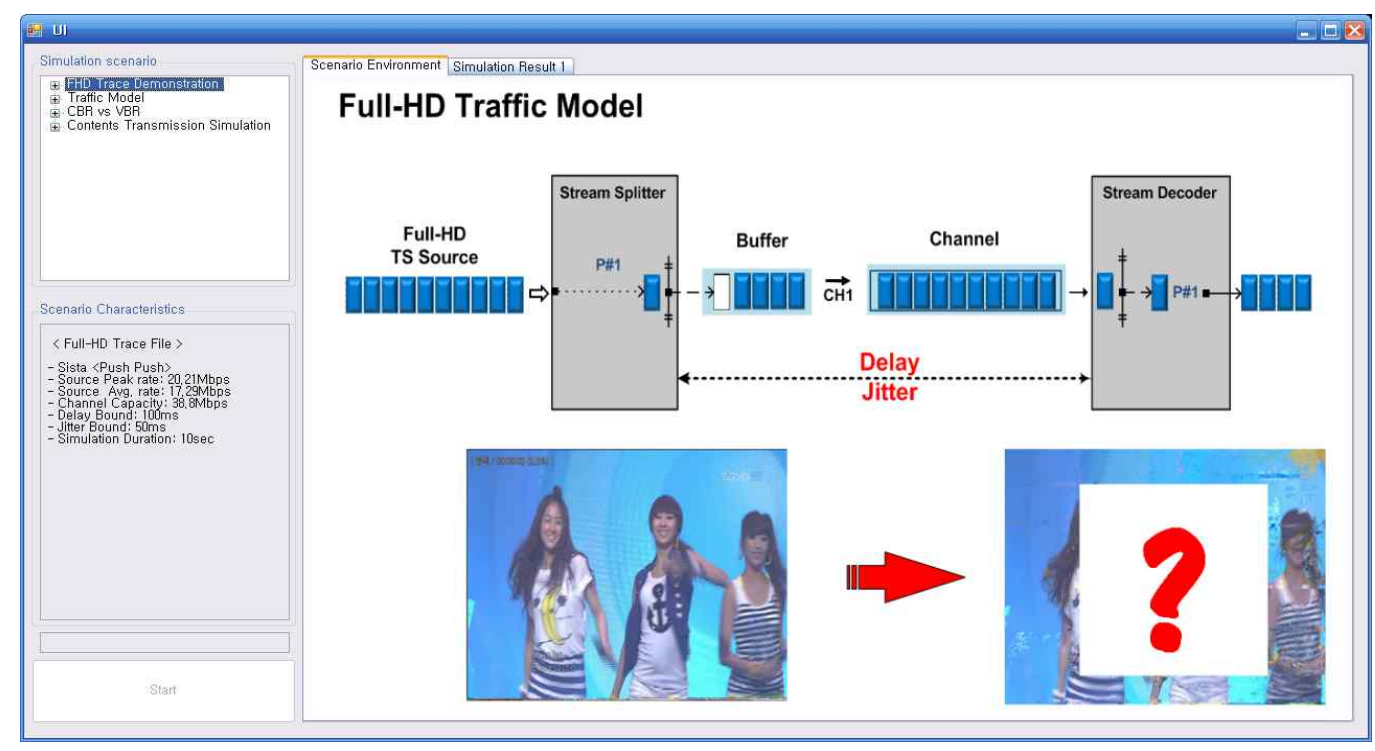

그림 6. 대용량 방송콘텐츠 전송 시뮬레이터의 UI

Fig. 6 . UI of the massive broadcasting contents transmission simulator 
Push 콘텐츠의 트래픽 특성을 보여준다.

표 1. 파트 | 시뮬레이션 특성

Table 1. Simulation characteristics of part I

\begin{tabular}{|c|c|}
\hline \multicolumn{2}{|c|}{ Part I Simulation Characteristics } \\
\hline Source & Full HD Sista <Push Push> \\
\hline Source Peak rate & $20.21 \mathrm{Mbps}$ \\
\hline Source Avg. rate & $17.29 \mathrm{Mbps}$ \\
\hline Delay & $60 \sim 150 \mathrm{~ms}$ \\
\hline Jitter & $10 \sim 100 \mathrm{~ms}$ \\
\hline Delay Bound & $100 \mathrm{~ms}$ \\
\hline Jitter Bound & $50 \mathrm{~ms}$ \\
\hline Channel Capacity & $38.8 \mathrm{Mbps}$ \\
\hline Simulation Duration & $10 \mathrm{sec}$ \\
\hline
\end{tabular}

시뮬레이션의 결과는 그림 7,8 과 같다. 그림 7 은 프로그

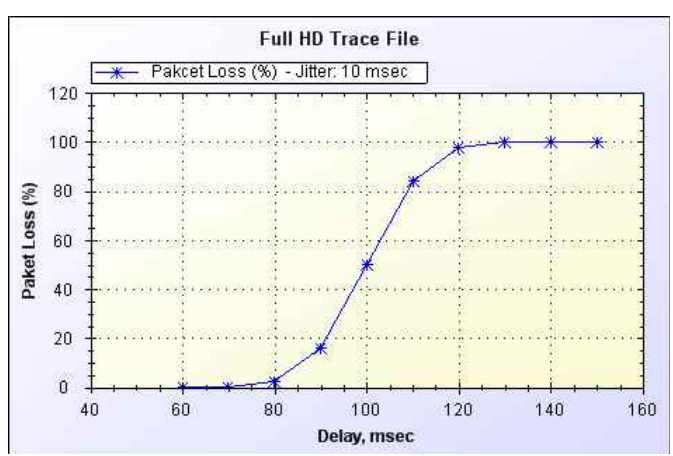

(a) 지터가 $10 \mathrm{msec}$ 일 때 Delay의 변화에 따른 패킷 손실률

그림 7. 지연 및 지터에 따른 패킷 손실률

Fig. 7. Packet loss ratio for delay and jitter
램의 전송과정 중에 발생하는 지연, 지터의 변화에 따른 패 킷 손실률을 나타내며, 그림 8은 지연, 지터에 따라서 손실 된 콘텐츠 재생함으로써 패킷 손실 정도가 실제 콘텐츠의 질적으로 미치는 영향에 대하여 나타낸다. 그림 7(a)에서는 지터가 $10 \mathrm{msec}$ 일 때 지연이 $80 \mathrm{msec}$ 이상에서 패킷 손실률 이 급격히 증가함을 확인할 수 있으며, 그림 7(b)에서는 지 연이 $60 \mathrm{msec}$ 일 때 지터가 증가할수록 패킷 손실률이 증가 함을 확인할 수 있다. 그림 8 에서는 지터가 $10 \mathrm{msec}$ 일 때 지연의 증가에 따른 화질 열화 정도를 나타내는데 그림 8(b),(c)와 같이 지연이 $70 \mathrm{msec}$ 이상 일 경우 영상의 화질 열화가 심각한 것을 확인 할 수 있다.

파트 $\Pi$ 는 영상 압축방식에 따른 방송콘텐츠 전송 시뮬 레이션을 목적으로 한다. 트래픽은 현재 비디오 응용에서 주로 사용하는 압축방식인 MPEG-2와 H.264/AVC 트래픽

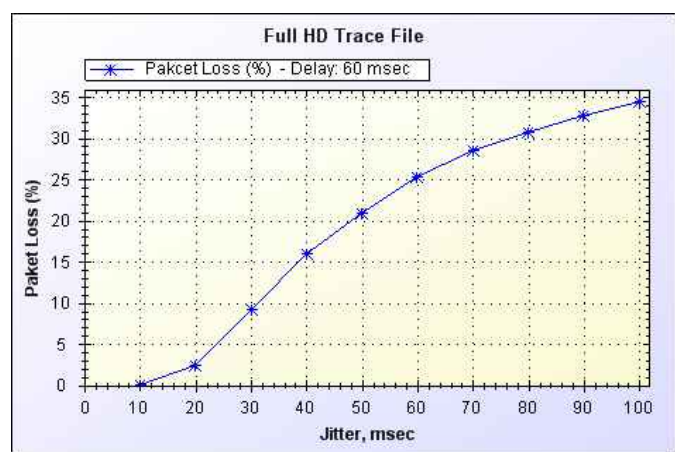

(b) 지연이 $60 \mathrm{msec}$ 일 때 Jitter의 변화에 따른 패킷 손실률

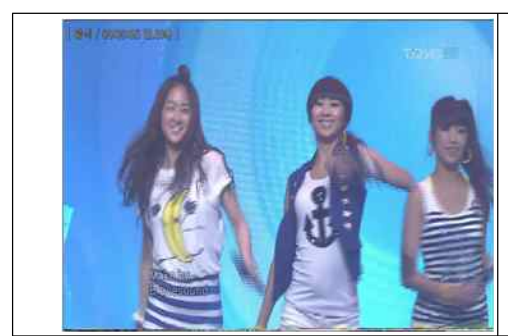

(a) Delay: $60 \mathrm{msec}$ Jitter: $10 \mathrm{msec}$

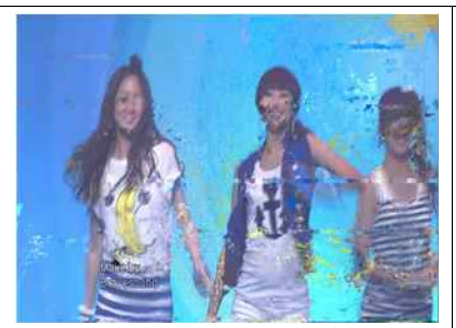

(b) Delay: $70 \mathrm{msec}$ Jitter: $10 \mathrm{msec}$

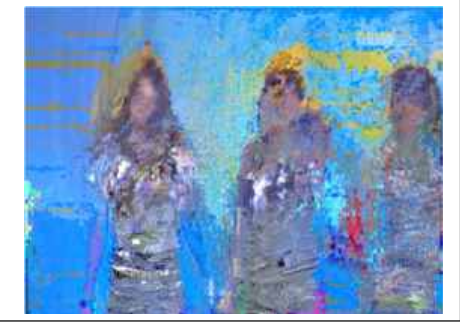

(c) Delay: $80 \mathrm{msec}$ Jitter: $10 \mathrm{msec}$

그림 8. 지연 변화에 따른 화질 열화 정도

Fig. 8. Image degradation for delay 
표 2. 파트 II 시뮬레이션 특성

Table 2. Simulation characteristics of part II

\begin{tabular}{|c|c|c|c|c|}
\hline \multicolumn{5}{|c|}{ 파트 II Simulation Characteristics } \\
\hline Source & $\begin{array}{c}\text { Pareto On-Off } \\
\text { Model }\end{array}$ & $\begin{array}{c}\text { Gamma } \\
\text { Distribution Model }\end{array}$ & $\begin{array}{c}\text { Full HD } \\
\text { MissA <Bad Girl } \\
\text { Good Girl> }\end{array}$ & $\begin{array}{c}\text { MKA UHD } \\
<\text { Bad Girl } \\
\text { Good Girl> }\end{array}$ \\
\hline Source Peak rate & $47 \mathrm{Mbps}$ & $49 \mathrm{Mbps}$ & $43 \mathrm{Mbps}$ & $87 \mathrm{Mbps}$ \\
\hline Source Avg. rate & $34 \mathrm{Mbps}$ & $37 \mathrm{Mbps}$ & $34.56 \mathrm{Mbps}$ & $69.12 \mathrm{Mbps}$ \\
\hline Delay Bound & \multicolumn{5}{|c|}{$38.8 \mathrm{Mbps}$} & $100 \mathrm{~ms}$ \\
\hline Channel Capacity & \multicolumn{3}{|c|}{$20 \mathrm{sec}$} & \\
\hline Simulation Duration & \multicolumn{2}{|c|}{10} \\
\hline
\end{tabular}

특성을 고려한 수학적 트래픽 모델 ${ }^{[2][13]}$ 을 적용한다. 수학적 트래픽 모델을 사용하여 다양한 트래픽 특성에 따른 성능 분석을 가능하게 하였다. 전송 방식은 본 논문에서 제안한 전송 방식을 기반으로 4 가지 시나리오에 대하여 콘텐츠를 전송한다. 채널 그룹 내 각 채널에 대하여 라운드 로빈 방식 으로 채널 버퍼에 패킷을 전송하며, 각 버퍼에서는 FIFO 방 식으로 패킷을 채널로 전송한다. 시뮬레이션 결과로 콘텐츠 의 개수와 결합되는 채널의 개수를 같은 비율로 증가 시키면 서 종단 간 지연과 패킷 손실 양을 관찰한다. 이를 통하여 채널 결합으로 인한 통계적 다중화 이득을 보여준다. 표 2는 파트 П에서 사용되는 소스의 트래픽 특성을 보여준다.

그림 9(a), (b)는 MPEG-2의 수학적 트래픽 모델의 전송 시간에 따른 트래픽의 종단간 지연과 패킷 손실량을 나타 낸다. MPEG-2 모델은 파레토 온-오프 모델을 사용하여 트 래픽을 구성하였고, 트래픽의 최대 전송속도는 $47 \mathrm{Mbps}$, 평 균 전송속도는 $34 \mathrm{Mbps}$ 의 특성을 갖는다. 결합된 채널 개수 와 콘텐츠 개수를 $1,2,3,4$ 개로 증가시킬수록 통계적 다중화 에 따른 이득으로 지연 및 패킷 손실량이 감소하였고, 특히, 4 개의 결합된 채널과 4 개의 콘텐츠를 전송할 경우에는 패 킷 손실이 없음을 확인할 수 있다. 이는 통계적 다중화가 만들어 내는 이득이 전송 대역의 효율을 높였기 때문이다. 그림 9(c), (d)는 H.264의 수학적 트래픽 모델의 전송 시간 에 따른 트래픽의 종단간 지연 및 패킷 손실량을 나타내며, 감마 모델을 사용하여 트래픽을 구성하였다. 표 2에서의 감 마 모델 특성을 갖는 트래픽을 사용하였고, 파레도 온-오프 모델과 같이 결합된 채널 수와 콘텐츠 수가 증가할수록 지
연 및 패킷 손실량이 감소하는 것을 확인할 수 있다. 그림 9(e), (f)는 FHD 콘텐츠의 트래픽 종단간 지연 및 패킷 손 실량을 나타내며, 그림 $9(\mathrm{~g}),(\mathrm{h})$ 는 UHD 콘텐츠의 트래픽 의 종단간 지연과 패킷 손실량을 보여준다. UHD의 경우 전송용량이 매우 크기 때문에 두 채널 이상이 결합된 순간 부터 측정하였다. 그림 $9(\mathrm{~g})$ 로부터 최대 약 $90 \mathrm{~ms}$ 크기의 지 연을 갖는 것을 확인 알 수 있으며, 이 경우 그림 9(h)로부 터 패킷 손실이 발생하는 것을 확인할 수 있다. 그림 9의 결과로부터 채널 결합의 수가 증가 할수록 콘텐츠의 지연 및 패킷 손실량이 감소하는 것을 확인할 수 있고, 이로부터 통계적 다중화 효과를 기대할 수 있다.

파트 III의 기능은 $\mathrm{CBR}$ 콘텐츠와 $\mathrm{VBR}$ 콘텐츠 전송을 통 해서 $\mathrm{VBR}$ 콘텐츠의 통계적 다중화 이득을 시뮬레이션을 통해 확인한다. 시뮬레이션의 시나리오는 VBR 콘텐츠의 최대 전송속도는 $43 \mathrm{Mbps}$ 이고, 평균 전송속도는 34.56 $\mathrm{Mbps}$ 하고, $\mathrm{CBR}$ 콘텐츠의 전송속도는 $38.8 \mathrm{Mbps}$ 이다. 채널 용량이 $38.8 \mathrm{Mbps}$ 인 채널 9 개를 결합하였을 때, $\mathrm{VBR}$ 콘텐 츠의 수를 증가 시키면서 성능을 평가하여 전송 가능한 콘 텐츠의 수를 $\mathrm{CBR}$ 의 콘텐츠 수와 비교한다. 그림 10 (a)는 VBR 및 CBR 콘텐츠 수에 따른 지연, 그림 10(b)는 VBR 및 $\mathrm{CBR}$ 콘텐츠 수에 따른 패킷 손실률을 나타낸다. 그림 10 으로부터 VBR 콘텐츠가 최대 11 개까지 CBR 콘텐츠가 최대 9개까지 수용 가능함을 확인할 수 있고, 즉 VBR 콘텐 츠의 통계적 다중화 효과를 기대할 수 있다. 표 П에 사용된 Full HD MissA < Bad Girl Good Girl>소스가 파트 피에서 입력 소스로 사용되었다. 


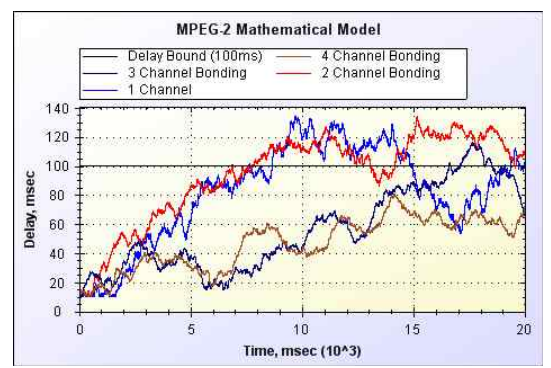

(a) 파레토 모델에서의 시간에 따른 Delay 변화

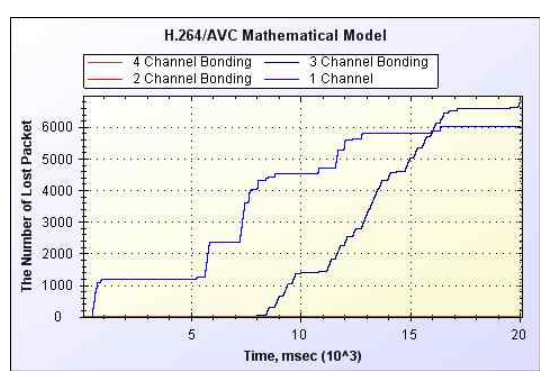

(d) 감마 모델에서의 시간에 따른 패킷 손실량

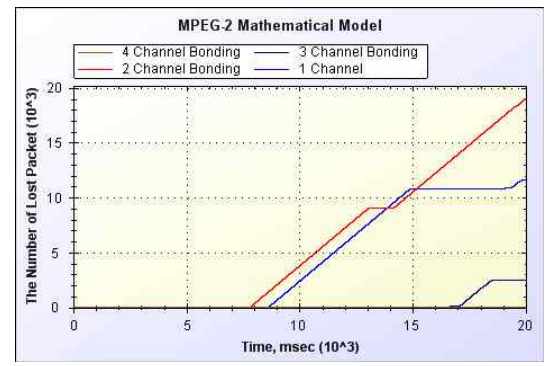

(b) 파레토 모델에서의 시간에 따른 패킷 손실량

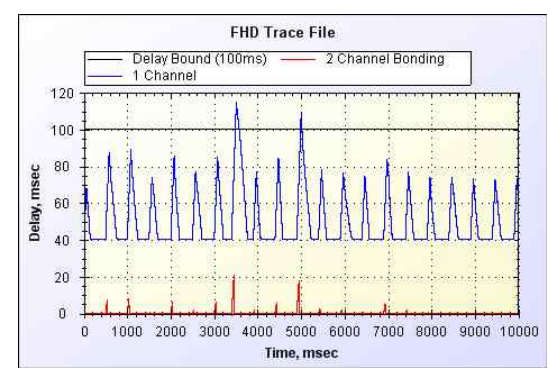

(e) FHD 콘텐츠의 시간에 따른 Delay 변화

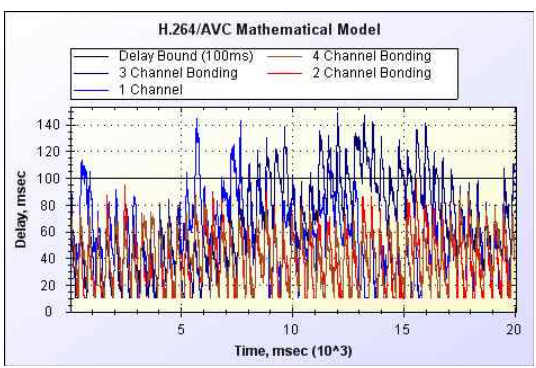

(c) 감마 모델에서의 시간에 따른 Delay 변화

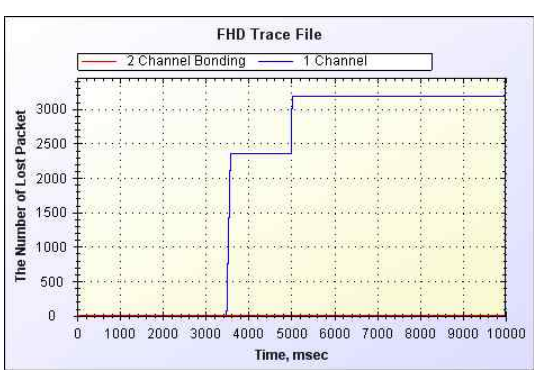

(f) FHD 콘텐츠의 시간에 따른 패킷 손실량

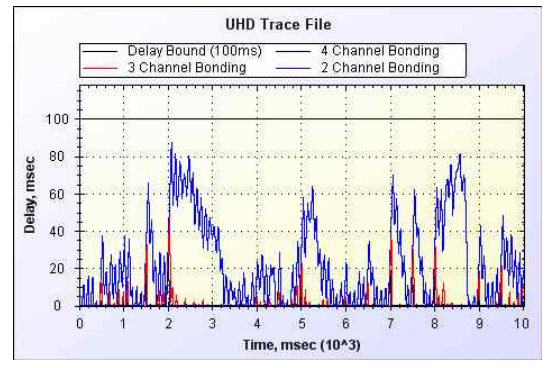

(g) UHD 콘텐츠의 시간에 따른 Delay 변화

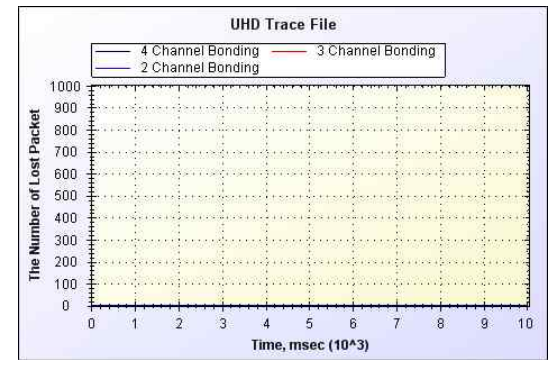

(h) UHD 콘텐츠의 시간에 따른 패킷 손실량

그림 9. 압축방식 및 콘텐츠 종류에 따른 지연과 패킷 손실량

Fig. 9. Delay and packet loss for video compression and contents

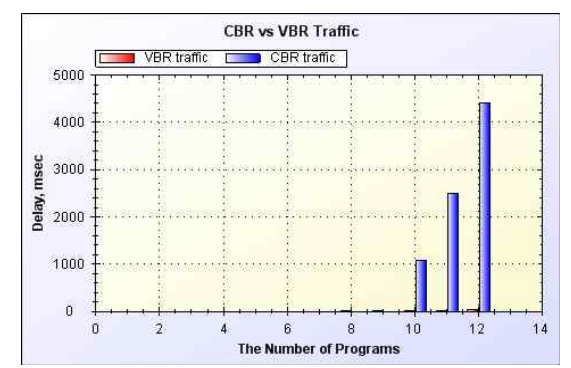

(a) CBR과 VBR 콘텐츠 수 증가에 따른 Delay

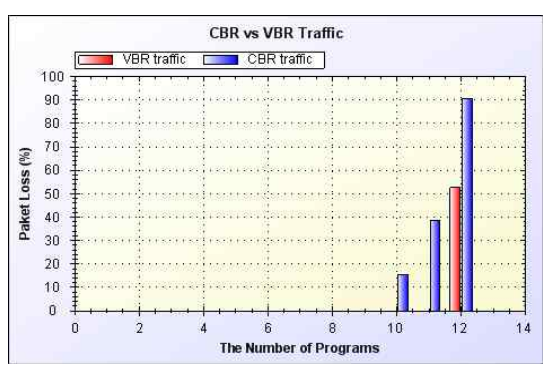

(b) CBR과 VBR 콘텐츠 수 증가에 따른 패킷 손실률

그림 10. CBR과 VBR 전송에 따른 Delay와 패킷 손실률

Fig. 10. Delay and packet loss for CBR and VBR 
표 3. 파트 IV FHD 트래픽 특성

Table 3. FHD traffic characteristics of part IV

\begin{tabular}{|c|c|c|c|c|}
\hline \multicolumn{5}{|c|}{ 파트 IV Simulation Characteristics } \\
\hline Source & $\begin{array}{c}\text { HD } \\
\text { MissA <Bad Girl } \\
\text { Good Girl }\end{array}$ & $\begin{array}{c}\text { Full HD } \\
\text { MissA <Bad Girl } \\
\text { Good Girl> }\end{array}$ & $\begin{array}{c}\text { 4K UHD } \\
\text { MissA <Bad Girl } \\
\text { Good Girl> }\end{array}$ & $\begin{array}{c}\text { MissA UHD } \\
\text { <ad Girl } \\
\text { Good Girl> }\end{array}$ \\
\hline Source Peak rate & $21 \mathrm{Mbps}$ & $43 \mathrm{Mbps}$ & $87 \mathrm{Mbps}$ & $174 \mathrm{Mbps}$ \\
\hline Source Avg. rate & $17.28 \mathrm{Mbps}$ & $34.56 \mathrm{Mbps}$ & $69.12 \mathrm{Mbps}$ & $138.24 \mathrm{Mbps}$ \\
\hline Delay Bound & \multicolumn{3}{|c|}{$38.8 \mathrm{Mbps}$} \\
\hline Channel Capacity & \multicolumn{3}{|c|}{$10 \mathrm{sec}$} \\
\hline Simulation Duration & \multicolumn{3}{|c|}{} \\
\hline
\end{tabular}

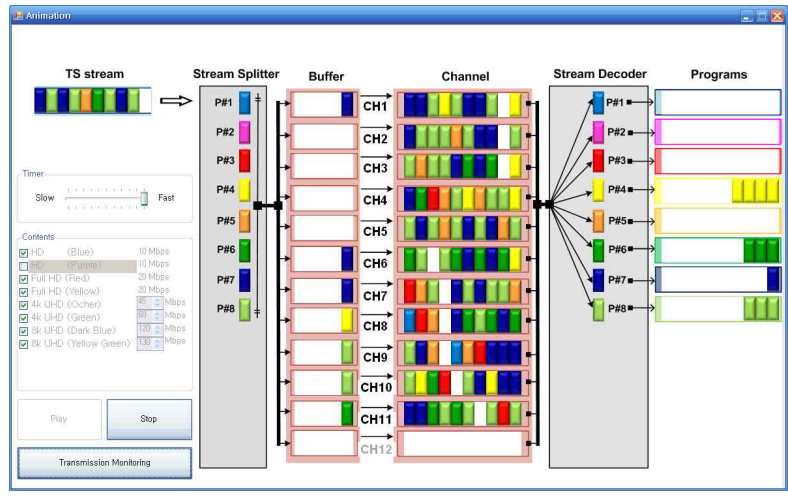

(a) 시뮬레이터의 애니메이션

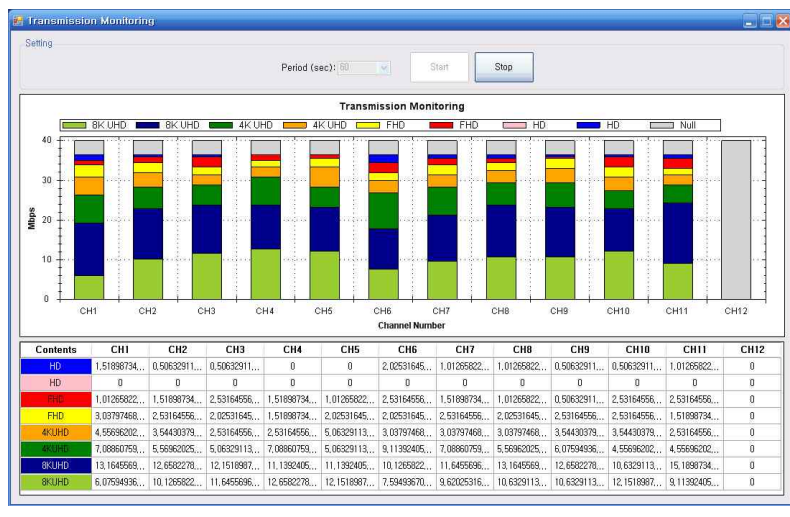

(b) 시뮬레이터의 전송 모니터링 시스템

그림 11. 시뮬레이터의 애니메이션과 전송 모니터링 시스템

Fig. 11. Animation and transmission monitoring system of the simulator

파트 $\mathrm{IV}$ 의 기능은 다채널 콘텐츠를 채널 결합 방식을 사용하여 전송하는 것을 애니메이션으로 보여주는 시뮬 레이션이다. 시뮬레이션은 총 8 개의 프로그램(HD 콘텐츠 2 개, $\mathrm{FHD}$ 콘텐츠 2 개, $4 \mathrm{~K} \mathrm{UHD}$ 콘텐츠 2 개, $8 \mathrm{~K} \mathrm{UHD}$ 콘 텐츠 2개)으로 그림 11 과 같이 구성되어있다. 실제 UHD 콘텐츠를 확보하는 데에는 어려움이 있어 $\mathrm{FHD}$ 콘텐츠 4 개와 16 개를 병합하여 $4 \mathrm{~K} \mathrm{UHD}$ 콘텐츠와 $8 \mathrm{~K} \mathrm{UHD}$ 콘텐 츠를 제작하였다. 이때 사용된 $\mathrm{FHD}$ 트래픽 정보는 표 3 과 같다. 이러한 애니메이션을 통해서 대용량 방송서비스 에서의 전송을 위한 채널 결합의 필요성을 제시하고, 나 아가 효율적인 채널 결합 및 자원할당 방식의 필요성을 인식시킨다.

\section{V. 결 론}

본 논문에서는 OPNET을 사용하여 실제 채널 결합 시 스템을 고려한 시뮬레이터를 제작하였다. 방송 매체접속 제어기술 시뮬레이션 시스템은 UHDTV 등의 초대용량 방 송콘텐츠를 효율적으로 전송하는데 필요한 방송 채널 결합 등에 있어, 핵심 기술 요소 및 관련 파라미터들을 도출 및 평가하기 위한 시뮬레이션 시스템이다. 시뮬레이션 시스템 을 통해 각 콘텐츠 용량에 따른 방송 채널 결합 방식 및 시그널링 과정 등을 시뮬레이션 할 수 있으며, 실제 $\mathrm{HD}$ 콘 텐츠를 사용하여 QoS 파라미터에 따른 화질 열화 시연 기 능을 제공한다. 또한 채널 결합을 통한 병렬 전송의 성능을 
분석하여 채널 결합 기반 대용량 방송서비스에 적합성을 평가 할 수 있다. 본 논문에서는 기존의 간단한 알고리즘을 적용한 전송 시스템을 제안하였지만 향후 최적화된 전송 알고리즘을 제안할 계획이다.

\section{참 고 문 헌}

[1] 정세윤, 조숙희, 이응돈, 김성훈, 최진수, 홍진우, "UHDTV 기술현황과 전망," 전자공학회지, 제 36 권, 제4호, pp. 427-435, 2009년 4월

[2] "UHDTV Roadmap", ICT Standardization Roadmap 2010

[3] 한운영, “디지털 케이블TV 기술 및 향후 전망”, 대한전자공학회지, 제 35 권, 제9호, pp. 58-69, 2008년 9월

[4] 조창연, 허준, 김준태, "초 고화질 텔레비전 방송을 위한 차세대 오픈 케이 블 방식에 대한 연구”, 방송공학회논문지, 제14권, 제2호, pp. 228-237, 2009년 3월

[5] Data-Over-Cable Service Interface Specifications DOCSIS 3.0, MAC and Upper Layer Protocols Interface Specification, CM-SP-MULPI v3.0- I08-080522, Cable Television Laboratories, Inc., MAY, 2008.
[6] 조성민, 박승권, "HFC 기반 가입자 전달망 기술", 한국통신학회지, 제 22 권, 제12호, pp. 21-32, 2005년 12월

[7] M. Tayer, "VBR/StatMux for Digital Broadcast, VOD and SDV", SCTE Cable-tec Expo 2007, pp. 1-18

[8] 노선식, “채널 결합 기반 상향스트림 스케줄링 알고리즘 설계와 성능평 가", 대한전자공학회, 제46권, 제5호, pp. 8-18, 2009년 5월

[9] S. Moser, J. Martin, J. M. Westall and B. C. Dean, "The Role of Max-min Fairness in DOCSIS 3.0 Downstream Channel Bonding", IEEE Sarnoff Symposium 2010, pp. 1-5, April 2010

[10] W. Al-Khatib, A. Rajeswari and K. Gunavathi, "Bandwidth Allocation Algorithm for DOCSIS Based HFC Broadband Networks," ICSCN '07. pp. 452-458. Feb. 2007

[11] ITU-T Rec. Y.1541, "Network Performance Objectives for IP-Based Services," May 2002.

[12] P.P. Pande, C Grecu, M. Jones, A. Ivanov and R. Saleh, "Performance Evaluation and Design Trade-Offs for Network-on-Chip Interconnect Architectures", IEEE Transactions on Computers, vol.54, no. 8, pp. 1025-1040, 2005

[13] H. Koumaras, C. Skianis, G. Gardikis and A. Kourtis, "Analysis of H.264 Video Encoded Traffic", INC 2005, July 2005

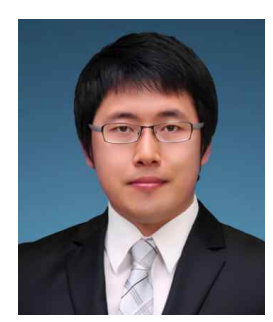

\section{신 현 철}

- 2009년 : 아주대학교 전자공학부 학사 졸업

- 2009년 3월 현재 : 아주대학교 전자공학과 석박통합과정

- 주관심분야 : UHDTV 전송시스템, Sensor Networks

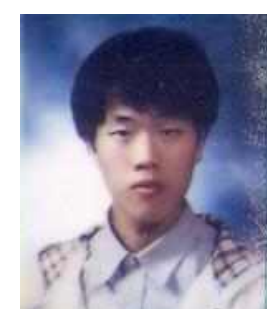

\section{이 동 열}

- 2008년 : 아주대학교 전자공학부 학사 졸업

- 2008년 3월 현재 : 아주대학교 전자공학과 석박통합과정

- 주관심분야 : Game Theory, Wireless LAN, Mesh Network 


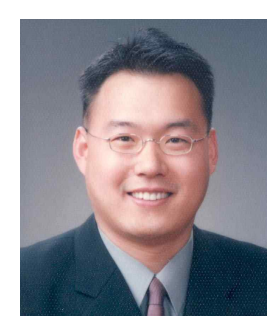

\section{유 웅 식}

- 1997년 : 충남대학교 컴퓨터공학과 학사 졸업

- 2000년 : 충남대학교 컴퓨터공학과 석사 졸업

- 2000년 4월 현재 : 한국전자통신연구원 선임연구원

- 주관심분야 : 3DTV/UHDTV 전송시스템, DOCSIS 프로토콜, 하이브리드 방송 등

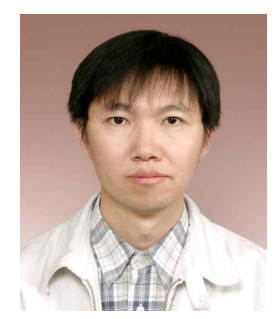

\section{최 동 준}

- 1991년 : 포항공과대학 전자전기공학과 학사 졸업

- 1993년 : 포항공과대학 전자전기공학과 석사 졸업

- 1993년 2월 현재 : 한국전자통신연구원 선임연구원

- 주관심분야 : 디지털 방송시스템, DOCSIS 프로토콜, 하이브리드 방송 등

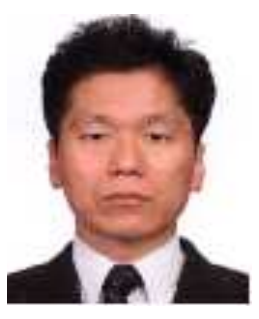

이 채 우

- 1985년 : 서울대학교 제어계측 학사 졸업

- 1988년 : 한국과학기술원 전자공학과 석사 졸업

- 1995년 : University of lowa 박사 졸업

- 1985년 1월 1985년 12월 : (주)금성통신 연구원

- 1988년 9월 1999년 3월 : 한국통신 선임연구원

- 1999년 3월 2001년 9월 : Lucent Technologies Korea 이사

- 2001년 9월 2002년 2월 : 한양대학교 겸임교수

- 2002년 3월 현재 : 아주대학교 전자공학과 부교수

- 주관심분야 : 광대역 통신망, Ubiquitous Networking, Traffic Engineering 